\author{
Research Article \\ (C) 2020 Carlos Miguel Ferreira and Sandro Serpa. \\ This is an open access article licensed under the Creative Commons \\ Attribution-NonCommercial 4.o International License \\ (https://creativecommons.org/licenses/by-nc/4.o/)
}

\title{
Contagions: Domains, Challenges and Health Devices
}

\author{
Carlos Miguel Ferreira \\ ISCTE-University Institute of Lisbon; \\ Interdisciplinary Centre of Social Sciences - CICS.NOVA; \\ Estoril Higher Institute for Tourism and Hotel Studies, Portugal \\ Sandro Serpa \\ Department of Sociology, \\ Faculty of Social and Human Sciences, \\ University of The Azores; \\ Interdisciplinary Centre of Social Sciences - CICS.UAc/CICS.NOVA.UAc; \\ Interdisciplinary Centre for Childhood and Adolescence - NICA -UAc, Portugal
}

DOI: https://doi.org/ 10.36941/ajis-2020-0056

\begin{abstract}
This article aims to understand the domains and uses of the various conceptual frameworks of contagion, its modalities and effects, in its different acceptations and historical contexts, as an expression of the process of interdependence between the stances and the different viewpoints of diverse actors involved with multiple scientific, moral, social and political challenges. Another objective focuses on understanding the process of collective management of contagion, disease and health, in which prevention is a critical element of its objectives and justifications, its discursive order and its practical activities.
\end{abstract}

Keywords: contagion, conceptual framework, health devices, disease

\section{Introduction}

The domains and conceptual uses of contagion, its modalities and effects, in their different meanings and historical contexts, express the interdependence between the distinct stances and viewpoints of different actors involved with multiple scientific, moral, social and political challenges.

Several assumptions underlie the literal or metaphorical use of the notion of contagion, inherent in these interdependent relationships between individuals and social structures in a given space-time. This concept can be mobilised to qualify the distribution of a medical and/or social phenomenon, characterised by its modalities of expansion, transmission and dissemination, by an exponential speed of propagation, sometimes linked to an unexpected origin and an unpredictable outcome. The notion of contagion often expresses fear, vulnerability, ignorance and helplessness, but it also involves the mobilisation of warning procedures and preventive mechanisms to deal with these disruptive situations. The discourses on contagion shape the normative justifications developed by institutions to formulate and implement coercive measures, notably excommunication or quarantine. Naming contagion enables naturalising a threat that a phenomenon of uncontrolled proliferation of an evil or disease poses in a given community, justifying the adoption of measures to manage that 
threat (Coste, Minard, \& Robert, 2011).

The notion of contagion is closely linked to the notion of contamination. Although these terms have a common Latin origin (contagion = cum tactus, contamination $=$ cum tangere) that refers to contact and the sense of touch, their syntax is distinct. The phenomenon that these notions describe is always relational, and the role ascribed to relata (elements or individuals placed in relationship) may be different. To describe a contagious phenomenon is to affirm, simultaneously, that one individual contaminates another individual and that these individuals may be only transmitters of something that they do not control. The notion of contamination has the role of specifying what happens to relata (a given individual has been contaminated, a given person has infected another person). In the contamination process, the causes and effects with their agents and patients are taken into account; contagion refers to a more impersonal, diffuse and involuntary process, in which the intentionality component is more difficult to assess (Coste et al., 2011; Cala, 2011; Marques \& Ferreira, 2010; Ferreira, 2020). The notion of contagion, historically associated with diffuse reactions of fear, did not originally refer to something known, which had a morphological structure, such as a microbiological agent capable of producing diseases in the body. Non-specific and much broader than the concept of transmission, the term contagion remained linked, until the $15^{\text {th }}$ century, to the term contact, used with the sense of «the act of exercising the sense of touch». Contagion relates the disease to the contact and the sense of touch. Until the $15^{\text {th }}$ century, the terms contagion and contact remained united and were used in the sense of «act of exercising the sense of touch» (Marques \& Ferreira, 2010; Nutton, 2000; Kuriyama, 2000; Pelling, 1993; Czeresnia, 1997). The danger of plagues was not only associated with the proximity of the sick that infected the healthy; talking to and caring for the sick, touching clothes or anything else that had been used or manipulated transferred the disease to the healthy individual. The objects of the sick or the dead also contaminated and killed animals in a short time (Czeresnia, 1997).

From the $16^{\text {th }}$ century onwards, the verbal form to contaminate - from late Latin contaminare started to be used mainly in the sense of contaminating, whereas the term contact maintains the same previous meaning (Cunha, 1982). From the $19^{\text {th }}$ century on, the contagion was defined as «transmission of disease from one individual to another». Since then, the term to transmit - with the meaning of «delivering, sending; letting go beyond; announcing» - started to be used also in the sense of "transmissible», becoming synonymous with contagion (Cunha, 1982). The concept of transmission emerges with the displacement of the perceptual structure. Likewise, the discourse about the spread of epidemics also moves from the imprecise senses of smell and touch to the sense of sight (Czeresnia, 1997).

\section{Methodology}

The methodology followed in this article is intensive in nature. The purpose is to understand the multiplicity of features and dimensions that characterise this polyhedral process of the social shaping of contagion.

This research favoured the document analysis technique, developed from different types of documentary sources. In a documentary study, documents can be understood as «means of communication», created for a given purpose and goal. They can be understood as a way of contextualising information and are analysed as communicative devices methodologically developed in the production of versions about events (Flick, 2005). Considering that documents are communication instruments and supports, which express objective forms of experiences and knowledge related to a given sector of human practices, this means that the whole document is subject to contextualisation within a given social and cultural framework. In this framework marked by its complexity, the document relates to the framework of social relationships and takes on a given role in the game of social relationships, ascribing value to some acts or shaping some relationships (Lalanda-Gonçalves, 2014).

The type of favoured documentary sources encompasses journals with medical and assistance 
focus, handbooks, academic theses and articles produced in the medical and social sciences fields, which, when expressing different stances and interests in the medical, assistance, political and societal fields, were important in understanding the construction of the discursive space on the shaping of social contagion and the modalities of its medical and political management. These documents are and express cognition policies: language is used to build an «official» reality often around categorisations that produce the promotion or marginalisation of ideas, as well as the current concepts, which selectively define situations and shape readers' preferences, perceptions and cognitions. These documents may be viewed as places of symbolic struggles of the perception of the social world. These symbolic struggles can take on two different forms. The objective form shapes the possibility of acting through individual or collective representation actions, which aim to show and promote some realities. The subjective form models the possibility of acting in the attempt to change the categories of perception and appreciation of the social world, the cognitive and the evaluative structures: the categories of perception, the categorisation systems, that is, the words, the names that build the social reality as much as they express it (Carvalho, 2000; Ramos, 1981).

\section{Contagions: Knowledge and Beliefs}

The lexical field of contagion (contamination, infection, epidemic, pandemic...) is, currently, perceived as being structured based on the discourses produced in the medical field. The medical notion of contagion regards the transmission of an illness from a patient to a healthy person. Contagion is essentially the transmission of disease. In all transmission, it is necessary to differentiate an act and an agent. The agent is the one who makes the transmission and the act is the transmission itself, viewed as a function. In the French language, the term contagion expresses the contagion-act and the term contage is used to express the contagion-agent. In English, Spanish and Portuguese, there is only the generic term contagion, contagio and contágio to express the function and the agent. Contagious diseases can be transmitted by touch, by direct contact between humans, without the need for an intervening vector or vehicle. A communicable (or infectious) disease is caused by the transmission of a specific pathogen agent to a susceptible host. Infectious agents can be transmitted to humans: directly, from other infected humans or animals, or indirectly, through vectors (insects or animals that transmit the infectious agent from person to person), airborne particles or other vehicles (contaminated objects or elements, such as clothing, cutlery, water, milk, food, blood, plasma, parenteral solutions or surgical instruments) (Bonita, Beaglehole, \& Kjellström, 2006). Although molecular biology has made the original explanatory model much more complex, this model remains satisfactory: an organic agent passes from one individual to the other, producing in the latter the disorders observed in the former (Paillard, 1998).

The «doxographical» discursive records produced on the medical notion of contagion express mnemonic linearity, an intention to build a narrative that emphasises the uninterrupted continuity of the idea of contagion.

Numerous historians of medicine claim that the genesis of the idea of contagion through the transmission of a pathogenic germ is associated to Girolamo Fracastoro, who, in the book De Contagione et Contagiosis Morbis et Curatione, published in 1546, claimed that the Napolitan Disease, syphilis, had a contagious nature. Fracastoro advocated the principle of contagium - pathogenic transmission through seminaria - regarding the plague and syphilis. This doctor identified three forms in the contagionist model: direct contagion, through touch; indirect contagion, due to personal effects or goods; and remote contagion through the air, following the airborne creed. However, his role as «creator» of the modern theory of contagion is questioned. The seminaria that Fracastoro invokes to explain contagion are viewed as non-living beings, that is, ancestors of bacteria, but they are sympathia and antipathia rerum in nature (Pantin, 2005; Nutton, 1990; Robert, 2011).

Frascatoro, Massa and Kircher, regarded as forerunners of contagionism, as well as Bertrand, one of the main $18^{\text {th }}$-century contagionists, do not call into question the Hippocratic tradition when explaining contagion by the presence of «invisible animalcules», not clearly distancing themselves 
from the miasma perspective: «animalcules» are described as «worms that float in the atmosphere» (Fabre, 1998). Respect for the Hippocratic tradition is a requirement for admittance to the medical field and, consequently, acknowledgement as a doctor, and helps to understand the almost null acceptance of contagionist theses of the origin of the epidemics. The admittance requirement is competence, the incorporated scientific capital, which has become the meaning of the game, but it is also the appetence, the libido scientifica, the illusio, the belief not only in what is at stake, that is, in the fact that the game is worth being played (Bourdieu, 2001).

It should be noted that the medical debate on the origin of epidemics, particularly the plague, opposing two different perspectives - the miasma theory and the contagionist theory -, developed from the $16^{\text {th }}$ to the $18^{\text {th }}$ century. The miasma theory is based on the idea of air corruption. In the contagionist theory, the individual is the agent of transmission, the body that carries the disease, whom, by touching, contaminates. Until the $18^{\text {th }}$ century, it was assumed that the «pestiferous» contaminated the air surrounding them. The miasma doctrine is not based on a pure and simple denial of contagion; it refuses to ascribe contamination only through direct contact, through touch. According to the miasma doctrine, the disease is the result of an atmospheric infection, the corruption of the air. It is explained by the evil influences of the sky, the poisonous vapours, the miasmas that rise from the putrid waters or that are released from the decomposing corpses. To these pestilences, the supporters of this doctrine oppose a medicine of odours, good or bad according to the currents that doctors advocate (Fabre, 1998).

Although Fracastoro advocated the idea that invisible living elements, the seminaria - which penetrated the body through the pores or the mouth during inspiration or swallowing -, were at the origin of contagious diseases, Terrentius Varron (116-27 BC) had long before argued that the animalia minuta were likely to transmit diseases (Paillard, 1998; Penso, 1981). For Patrice Bourdelais, until the beginning of the $19^{\text {th }}$ century, there was no strict distinction between contamination, infection and contagion, despite Fracastor's work on the contagion of syphilis and his intuitive description of infravisible germs (Bourdelais, 1998). These stances reveal the "proto-idea» of living and invisible pathogenic elements that marked the ways of «seeing and doing» of the agents that advocate the bacteriological/microbiological thinking style. The "proto-ideas» encompass all the allusions of the past that are capable of making prior reference to everything that is adopted by the collective of thought and that influence the establishment of the networks of meanings created by the scientist, such as concepts (Fleck, 1986).

However, it is safe to affirm that the genesis and the primordial use of the notion of contagion did not have a medical origin and acceptance and that the lexical appropriation movement took the opposite direction: from evil to disease. The idea of contagion developed with a strong moral connotation, which describes the possible spread of evil, rather than the disease (Fossier, 2011). In the West, until the $13^{\text {th }}$ century, the topic of moral contagion developed in a theological context (contagion of sins, vices and heresies) with no explicit reference to the contagion model created by medicine, albeit diseases such as the plague and leprosy have always been associated with vices. In the Christian and Latin world, the first uses of the terms contagium and contagio emerged in doctrinal or normative texts, harshly condemning heretical groups. In the early incipient theology of the first centuries of Christianity, both terms were used to designate the transmission of the original sin from one generation to the next. These notions were decisive in shaping the medieval sphere of the sacred, which encompasses what was neither contaminated nor polluted by original sin. The notion of contagio became the reference of the disciplinary mechanism developed by the Church, which, in the face of the spread of evil, wavered between the pastoral solicitude, the institution of the denunciation, and the devices of exclusion (fines, excommunication, exile, corporal punishment) (Fossier, 2011).

During the Middle Ages, common representations, on the one hand, continue to emphasise certain diseases, namely leprosy as a disease of the soul, a consequence of sin and divine punishment. On the other hand, these representations express an epidemic dimension that would reach, above all, popular classes, the poor and the miserable who questioned the dominant social order. However, the 
moral aspects had the greatest visibility, shaping their public perception. Leprosy was seen as an evil, a very contagious disease, and its transmission was associated with an illicit and sinful sexual life: to the «wilfulness of the leper» (Cule, 2002).

Scholastic theologians admitted the contagious nature of sins, in which leprosy was the visible display of sin and its spread. This positioning illustrates the ambiguity of the epistemological status of contagion in the Middle Ages. From the $13^{\text {th }}$ century onwards, in the Latin world, a new theoretical framework for thinking contagion emerged, whose origin is medical, but whose uses far exceed this original framework. There was a progressing medicalisation of the theological discourse, which gained increasing visibility from the years 1240-126o on, with the access, in the West, to several Arab medical texts, mainly the Canon of Avicenna (Robert, 2011). However, theologians used the Canon to justify what, until then, was explained only through certain analogies with medicine, such as the status of Adam's body of or the Virgin's conception. The novelty of this model laid not so much in its rationalist or naturalistic nature, but rather in its ability to encompass, in addition to the spread of certain diseases, a series of cases without apparent links between them, such as the transmission of passions, vices and sins, the disease of love, as well as some phenomena traditionally belonging to the field of magic. In this process, theologians played a decisive and even paramount role in transforming the discourse on contagion (Robert, 2011).

The idea of leprosy contagiousness developed mainly in non-medical contexts, namely political ones, when it came to justifying the isolation of individuals categorised as «lepers» in leproseries, but also moral and theological contexts when the disease was linked to sexual bad habits and sin. Until the $14^{\text {th }}$ century, doctors did not associate leprosy with a contagious disease; rather, they viewed it as an individual disease that affected the whole body and whose origin would be connected with an excess of black bile. The only form of contagion accepted by doctors was the hereditary transmission. However, if the Priests of the Church viewed the contagion of original sin as a hereditary disease, Avicenna deemed leprosy to be a contagious and hereditary disease. However, several authors mitigate this parallelism, claiming that the modalities of hereditary transmission of leprosy were not the subject of consensus in the academic community of the $13^{\text {th }}$ and $14^{\text {th }}$ centuries. For some, the father was responsible, in some way, for the effects of the sin of the flesh, which infected the child; for others, it was the woman's lust and libido during sexual intercourse that perpetuated sin from one generation to the next. Between these two stances, there are several nuances. The main difference between the contagion of $\sin$ and the contagious or hereditary disease was the fact that the latter category did not affect all children or all people in contact with the sick, whereas the whole of humanity was affected by the contamination of original sin (Robert, 2011; Lugt, 2010).

This moral and metaphorical meaning of the contagion of heresies, sins and, later, crime and homicide expresses a process of naturalisation and moralisation of social phenomena, envisaged as potentially disruptive and difficult to control, involving the implementation of exceptional procedures. The coordination between measures of sanitary prophylaxis and penal repression mechanisms, as well as the emergence of institutions of seclusion and isolation (lazarettos, hospitals, nursing homes, prisons), were favoured. Furthermore, the more or less closed nature of these institutions would allow keeping the evil at a distance, but they could instead, by promoting physical and moral promiscuity, aggravate the proliferation of the diseases.

Paradoxically, the establishment of a medical theory of contagion opened, during the $19^{\text {th }}$ century, space for legitimising contagion theories applied to crowds, crimes, prison or literature. The notion of «moral contagion» was relevant to the elucidation of collective possession by the «sciences of the psyche». The establishment of criminal science as a specific disciplinary field developed, besides the definition of the psychological profile and the typological classification of dangerous individuals, from the initiative of doctors concerned with the amoral dimension of crime, aiming to establish epidemiology of crime with the purpose to prevent its contagious nature (enhanced by the imitation of facts conveyed by the press). The threat of moral contagion was also invoked to forbid the reading of works deemed dangerous. In 1818, a Portuguese royal censor wrote in one of his statements: 
«There are, however, in the French language, ungodly, seditious, inflammatory, and outrageously obscene books, directly produced and aimed to shake and subvert the throne, the altar and the good customs. It is against these, in particular, that censorial severity should be exercised, and more severe and vigorous measures taken than against the plague, the damage to which I think is much less than that of modern mental and moral contagion» (Neves \& Ferreira, 1989, p. 115).

Certain moral values are protected, and certain social rules are defined by beliefs in dangerous contagions. Moreover, the ideal order of society is maintained thanks to the dangers that threaten the transgressors (Douglas, 1991).

The idea of contagion without body contact, whether it is indirect or materialised through a vector, is present in numerous theories of contagion, in different societies. The transmission of the disease may not be associated with a simple material contagion, and the disease (whether transmitted by air or by the proximity of the other's body) can always be regarded as a tangible trace of impurity, of a symbolic world of impurity, induced by the social bond that ties the individual, categorised as contaminated and contaminable, with others and inherent to the demarcation of the boundaries between social order and disorder (Douglas, 1991; Cruz, 2007/2008). This symbolic dimension of impurity can shape cognitive assessments of non-contagious diseases - from the medical point of view - and can take on a contagious nature in the perceptions and representations expressed by sick individuals and others, in which contacts may be deemed dangerous and affect those who are closer to the patient. Contrary to the assumptions of biomedical conceptions, which circumscribe contagion to the biological and physiological sphere, clinically attested, patients assume that a certain disease, namely alcoholism, although not transmitted, may be contagious, affecting, above all, those who are close to the "alcoholic», that is, their family, friends and the work environment. The model of contagion of representations made by different patients differs from the idea of direct contamination. In other words, it does not suggest that the «alcoholic» individual's family and friends start drinking like the patient, but that they are affected by the drinker's disease. Alcohol, understood as a carrier of impurity, also «contaminates» the places where it is consumed. That is why the alcoholism recovery program is also called by the members of the «former alcoholics»' associations as an "avoidance program», in which the patient must avoid "the old habits», "the old friends» and «the old places» they used to go to in times of active alcoholism (Fainzang, 1994).

The belief in the contagion of non-contagious diseases and events perceived as dangerous can be identified with the symbolic dimension of the impurity that expresses the dangers incurred by the social order and the purity of a group, emerging as a guarantee of the avoidance of all physical and social proximity with patients and other individuals perceived as dangerous in a given community. This articulation between impurity, purification and prohibition of contact due to the belief in contagion shapes the symbolic management of internal and external dangers that threaten the several societies in different time-spaces. The topic of impurity and its purification via the removal of socially dangerous elements was present in Greek antiquity as a principle of social regulation; it endures in the Indian caste society; in the $19^{\text {th }}$ century, in Europe, the dangers of sexual freedom associated with the belief in syphilis developed an obsession with contagion. Recently, the HIV/AIDS epidemic has revived this fear. Several arguments were supported by far-right parties, which advocated, against the risks of contagion with AIDS, measures to exclude patients, which were as drastic as those regarding another social danger: immigrants (Hass \& Jodelet, 2007).

The perceptions and representations of contagion convey negative or deprecating cognitive sensations and assessments, which suggest the malignity of the other, the other as a source of threat and danger, raising a generic fear in which contact is perceived as a possibility of aggression and contamination. The notion of contagion is related to experiences of fear, exasperation, denial and rejection of the other, recalling the old attitudes of populations threatened by the plague, such as escape, purification and isolation (Bourdelais, 1989). The images linked to the notion of contagion in the case of the HIV/AIDS epidemic prompted social, economic and political reactions of such breadth and scope that it was named «third epidemic» or «epidemic of the year 2000» (Czeresnia, 1997; Fabre, 
1993) - that which produced social repercussions of panic, ignorance and stigmatisation of patients and the most affected social groups. The evidence of AIDS «contagiousness» was emphasised by its association with transgression and death. The notion of contagion was related to the connection of meanings of sin, punishment and guilt with the forms of transmission of the disease through sex and the use of drugs (Czeresnia, 1997). The medical-preventive discourse causes, concerning AIDS, a dissociation between communicable disease and contagious disease. HIV infection is categorised among communicable diseases, without ascribing it a contagious nature. The notion of transmission, by defining the specific ways in which the etiological agent of the disease passes on from one individual to the other, builds rationality that is capable of breaking with the fear linked to the classic notion of contagion. However, this rationality, made possible through the concept of transmission, is historically dated, and it is associated both with the emergence of medicine and the modern concept of disease. The notion of transmission guides the formulation of a preventive discourse, as well as the establishment of norms and laws that seek to define rights, duties and arguments in opposition to hostile and irrational attitudes against patients and the most affected social groups (Czeresnia, 1997; Fabre, 1993).

AIDS has been pronounced an epidemic; currently, the coronavirus (Covid-19) is seen as a pandemic, the new «plague». This «metaphorical virulence» is already embedded in its ethos. There are allusions to the «semantic contagiousness» because the nosos, in this type of contagion, is the meaning. The «plague» is «transmitted», to a great extent, in the discourses, through the meanings of death-contagion-big disease. In several religious, poetic and medical discursive records, the term pestis and its derivations indicate a terrible disease, a great disgrace or a polluted, contaminated, unhealthy, insane and often deadly condition. A contagious disease but, above all, the huge disease.

\section{Collective Management of Contagion}

In the collective management of contagion, disease and health, prevention is a critical element regarding its objectives and justifications, its discursive order and its practical activities.

Prevention takes different forms that may be clustered into four schemes: (i) the magicalreligious model, which incorporates the prohibitions and obligations in a sacred record to prevent or to reverse misfortune, through divinatory and propitiatory rituals; (ii) the profane constraint model, which derives from the political space and acts through social control, and whose paradigmatic form is the sanitary cord; (iii) the Pasteurian model, which, based on science and technology, is firmly inscribed on the field of effectiveness, illustrated by the historical successes of vaccination; and (iv) the contractual model, which assumes the acquisition of a partnership agreement, and in which health education is the pivotal figure. The reading of these models according to a chronological progression, in which each one of them is isolated, could make us believe in their linear succession. On the contrary, there is the sedimentation of these four schemes, and, in contemporary societies, whether close or distant, tensions crystallise between the forms of beliefs and the power they embody. Currently, prevention is a variable shape of the four models (Dozon \& Fassin, 2001). At the dawn of the $21^{\text {st }}$ century, there has been a reshaping of health policy, which favoured adding a culture of preparation (anticipating the emergence of diseases and their sanitary, economic and social consequences) to a culture of prevention (disease prevention). The «preparation» entails a set of notions, strategies and activities, and may be defined in a systematic way around three axes: the prevention of major epidemics through epidemiological monitoring and early detection of epidemic outbreaks; the establishment of swift responses, production and sharing of data, knowledge and technology; and the improvement of global governance response to epidemics (Lakoff, 2007, 2008; Torny, 2012).

In traditional societies, the collective management of adversity and disease is a poorly differentiated activity. This relative lack of differentiation is visible at two levels. On the one hand, the representations and practices mobilised are not a clearly circumscribed set. Both illness and death fall into the category of misfortune, which also includes other adverse events, such as the loss 
of a harvest or the poor result of a hunt, drought, floods or hunger; epidemics are, thus, part of a wider category of misfortune that societies face. In general, the same divination and conjuration procedures are used, the same diviners and the same oracles are consulted, and the same types of interpretation are put forth. On the other hand, prevention is a set of beliefs and rites that touch all social activities, rather than a set of knowledge related to the disease. In these societies, prevention, that is, the set of beliefs and actions by which individuals protect themselves from diseases and misfortunes emerges as the critical figure in the collective management of the disease. Prevention is based on the magical-religious model, which inscribes prohibitions and obligations in a sacred record to avoid or to reverse misfortune. This model relates to the set of interdictions and obligations, individual or collective prescriptions and proscriptions, divinatory practices and propitiatory rites, often accompanied by sacrificial rites and the making of protective objects (Dozon, 2001). The collective management of disease and adversity, which is a poorly differentiated activity, does not come from specific institutions (Fassin, 1996).

The growing social differentiation - the social division of labour, the urbanisation process, industrialisation and consolidation of functional and professional hierarchies - required the creation of new forms of functional regulation and coordination between social structures and individuals, also present in the collective management of the disease. The greater the differentiation, the greater the need for an institutional organisation that ensures the dominance, integration and interdependence of individuals (Mozzicafreddo, 1998). The historical processes of urbanisation and industrialisation, which led to the establishment of the urban and industrial society, caused a continuous growth of human interdependence, in its social and spatial dimensions. The conditions of deprivation and poverty of each social group affected the others, making it practically impossible for economic, political and social elites to escape the effects of the precarious living conditions of the poor and deprived population and to the diseases they spread (Swaan, 1988).

Epidemics may be viewed as paradigms of interdependence, expressing the "public evil» that affects the whole of society, the dominant and the dominated, albeit the social inequalities of exposure to risks and epidemic dangers are enhanced (Swann, 1988; Ferreira, 2020). The awareness of interdependence does not ensure the development of collective action. Diseases of an epidemic nature generated fear and distrust between rich and poor. Wealthy classes blamed the poor and held them accountable for the disease. The working classes accused the rich of having created these diseases to eradicate the poor. Public authorities established several provisions to impose medical discipline and compel the rich and the poor to accept public hygiene guidelines. These measures involved mandatory cooperation at different scales, namely at the local and national ones, between these social categories. State policies were the unforeseen historical result of a process of adopting measures to face precariousness and social poverty. In a first moment, these problems were addressed with individual and voluntary solutions. With the increase of their scale and complexity, collective, but still voluntary, ways of combating poverty and social need were developed. These forms, mainly related to voluntary institutional charity, found limits of scale, coordination and collective action, especially with the continued growth of the social problems to face, as well as the links of interdependence. This process led to the nationalisation of actions against deprivation, which were then made collective, compulsory and centrally coordinated (Swaan, 1988; Konstantinos, 1997).

Preventive administrative and health structures coordinated by the central government have emerged, albeit of an initially provisional nature, in the process of collective management of epidemics, namely health councils, sanitary cords, quarantines and lazarettos. Political agents held a dominant position vis-a-vis doctors, and there was a growing extent of their prerogatives in the various fields of social life. Concerning endemic diseases, their collective management was steered by the development of continued collective actions, because these diseases are linked to permanent problems that affect a given population. These diseases, defined socially as «social scourge» - which the problems of morbidity and mortality are inherent to, as permanent phenomena of a «population bio-politics» (Foucault, 1978) emerging throughout the $18^{\text {th }}$ century - express the institutionalisation of permanent concerns towards the health of the populations by the State, and not just sporadic, as 
public authorities had so far dealt with epidemics. The genesis of permanent concerns regarding the health of the populations by the State relates to a process that has two interdependent levels (Pinnel, 1998). The first is characterised by the increasing attention ascribed to health, the body and medicine in the royal courts. The life of the court opens space for the expression of a new sensitivity to the morbid manifestations of the body, which results in a search for medicine and doctors, and in the enthusiasm of courtiers and the urban bourgeoisie for a "profane» medical literature, popularising knowledge on pharmacopoeia. The second level of shifts regards the process of building the State as a relatively autonomous field, which exercises a power to centralise physical and symbolic strength, and which is inextricably accompanied by the institution of the unified social space it is responsible for (Bourdieu, 2014; Pinnel, 1998). The establishment of a public administration is interwoven with the progressive imposition of a triple royal monopoly: symbolic monopoly, fiscal monopoly and monopoly of legitimate violence, which characterises the emergence of the State (Bourdieu, 2014; Elias, 1983). The challenges posed to public administration in assessing the wealth of the kingdom have gradually brought up the notion of population, that is, a representation of the group of individuals who live in a given territory and who, through their work, produce wealth in different forms. The investment of political agents in the collective management of the disease enabled the emergence of an autonomous space of public health. The political may be viewed as being formed by power relationships mobilised in the public space for the control of decisions and actions whose object are collective goods (Fassin, 1996). In this way, the collective management of disease and health can be called public health from the moment it enters the political sphere, or, more precisely, when it is part of the formation and institutionalisation of the political where the government of life finds its place (Fassin, 1996). Thus, with the reinforcement of centralised political institutions, within the framework of the establishment of the modern western States, the collective management of disease and health, as public health, becomes part of the practice of the Government, hence inseparable from the State (Fassin, 1996). The State, as a political shape of society as a whole, in Norbert Elias's formulation, not only structures the relationships between society and the political authority but also, and above all, the relationships within society itself, notably in the influence it exerts on the structure and collective action (Mozzicafredo, 1998). However, if the establishment of a health order is part of the conditions for the establishment of States, understanding the transformations in the State structures inherent in collective health management is critical in the analysis of the process of the collective management of disease and health. Although the different European States were concerned with the health situation of the populations, this did not cause collective health management to adopt the same modalities and contours everywhere. The history of public health reveals, on the contrary, how much sanitary order is a reflection of the specific social and political structures in each place and at each time (Fassin, 1996).

Epidemics can be viewed, simultaneously, as revealing the interaction between the medical and the political world, and as catalysts of the dynamics of the collective management of the disease.

The collective management of the «plagues» and recurrent epidemic outbreaks was embodied in a set of specific procedures and institutions: health councils, sanitary cords, quarantines and lazarettos, which were the first preventive administrative and sanitary structures, coordinated by the central government, albeit initially of a provisional nature. They first developed in the Northern Italy states, in the $14^{\text {th }}$ and $15^{\text {th }}$ centuries, and spread in the following centuries to the various European states. These mechanisms to fight the epidemic express the dominant position of political agents over doctors. Decision-making power remained in the hands of the nobles who administered the health councils.

A set of sanitary procedures against the "plagues» was institutionalised since the $14^{\text {th }}$ and $15^{\text {th }}$ centuries, namely the control of travellers, vagrants, beggars and city residents; the establishment of quarantine; outside-the-walls houses, but fundamentally lazarettos. The establishment of the quarantine allowed the control by isolating people and goods affected or suspected for a specific period and under strict conditions - until it was established that they were not affected by the "plagues» in certain places deemed permanently affected, which implied continuous monitoring of a 
permanent danger. The sanitary cords were a sanitary mechanism mobilised to prevent the proliferation of epidemics, consisting of one or more concentric lines of defence around the place to protect. This mechanism could also include terrestrial lazarettos and the use of a system of individual health tickets for travellers. Outside-the-walls houses and, above all, lazarettos, as sanitary and control spaces that followed a prison logic, were deemed vital to isolate suspected or infected patients to «be treated or die outside the city». These mechanisms took into account the degree of danger of the migrants' place of origin, the estimated incubation time of the disease in question, the capacity of the goods to retain morbid influence and certain categories of travellers deemed extremely dangerous, such as immigrants and pilgrims (Bonastra, 2010). The emergence of these disciplinary mechanisms was thus the materialisation of the "political dream of the plague» of ordering the disorder. The critical fact becomes the institutionalisation of public health by the State, that is, the establishment of an administrative mechanism whose purpose was the collective management of a disease, its monitoring and prevention.

The system of quarantine and lazarettos was based on a logic of exclusion and purification of people categorised as the «other», of goods and places considered unhealthy or affected by pestilences. The time gap between catching the disease and its development was also a cause for fear. The apparent state of health of the contagious person was another dilemma that those responsible for public health had to deal with, and which shaped the quarantine as an institution that was not intended to fight the disease itself, but rather to counter the possibility of the plague's emergence. The defence procedures, albeit based on the total exclusion of communications - prevention -, sought to develop a filter that did not completely interrupt communications and were based on the categorisation of the suspect vis-a-vis the patient's evidence. The time factor in the quarantine played a very important role: the ascertainment of a time of incubation of the disease in the carrier of the contagious disease, during which the appearance is healthy, justified the establishment of a system based on the prevention of the disease (Bonastra Tolós, 2006).

The old and the new lazaretto originated in Venice, respectively in 1373 and 1418, both of which were spaces of isolation and defence. While the former remained a place of piety, the place of assistance provided by charitable hermits, experts in caring for the «lepers», the latter was a place of control, following, in some respects, the procedures for admittance and distribution used in hospitals, such as the admittance to the quarantine of suspected cases and the transfer to the old lazarettos of those who were deemed contaminated (Cosmacini, 1992). In general, a distinction was made between the «infected» and the «suspect». An «infected» person was someone whose contagious disease had been diagnosed by a doctor or a surgeon. On the other hand, «suspects» were all those who had come into contact with an affected person or objects thought to be infected, as well as all people from a space that was supposed to be pestilent (Cipolla, 1976).

The lazaretto was a non-ambiguous closed space. A space with a hospital structure, outside the city, but not opposed to it. A space created for a temporary, transitional period. A space that is not simply closed, but completely barricaded. A space for segregation for extremely contagious and extremely dangerous individuals, even if the patients were not necessarily irrecoverable, although the virulence of the disease rarely left room for a possibility of cure (Cosmacini, 1992). The lazaretto was a sanitary establishment based on a prison logic. This confinement was a collective act, since it acted on travellers, goods and ships in transit, even when the nature of their health license exempted them from complying with quarantine. The heart of the institution was centred on the suspicion that continually targeted everyone and, at any time, an exemplary will could impose quarantine on the boat least prone to contagion. The logic of the quarantine was based on the secrecy of the operations that took place in the lazaretto, expressing an absolute power of the authorities of this health establishment, aiming to avoid all physical communication and compartmentalise spaces suitable for individuals and goods, but also enable the control of information. Another relevant element was the exemplary nature of penalties for non-compliance with quarantine rules and for any suspect who arrived at the ports. The lazaretto authorities were able to impose long quarantines, burn cargo, block the docking of ships that came from infected areas, and there was, in many of their interventions, an 
intention of exemplarity (Bonastra Tolós, 2006, Bonastra, 2010).

While quarantines, lazarettos and disinfection measures were conveyed in medical and political discourses as the most effective mechanisms to contain epidemic phenomena, for the vast majority of populations, the impotence to face the spread of "pestilences» raised the belief that getting away from infected areas would be the best way to protect themselves from epidemics. Cito, longe, tarde: running away as quickly as possible, to a distant place and for a long time. In a situation of outburst, people, especially the most socially favoured, abandoned their activities and left the affected cities in a phase of total disorganisation, to take refuge in places, preferably in the neighbouring rural spaces, which they hoped to be more merciful. This behaviour allowed them to face the disruptive fear of contagion, or, in another perspective, they could experience an idyllic exile, as Boccaccio pointed out, or a temporary refuge before returning to the city, as Defoe maintained (Boccaccio, 2003; Defoe, 1966; Martins, 2011). Paradoxically, this decision to escape the fear of the plague, the «absolute evil», added to the exponential spread of the disease.

The circumstantial coalitions of interests that shaped the strategies and actions developed by different agents from distinct social spaces (political, medical and religious), enabled the acknowledgement and legitimisation of the «social scourge» linked to epidemics and the promotion of their public management. They contributed to the definition and implementation of health policies, as well as to the promotion and development of new specialised institutional areas (sanitary cords, lazarettos, quarantine), intervening in the shaping of collective management of health and diseases categorised as contagious. Several relevant components in this process can be put forth: the personalisation of the scourge, of religious inspiration, led to many excesses, but favoured the establishment of an objective relationship between the movement of people and the development of epidemics; the structuring of powers enabled institutional sanitary confinement that materialised through the construction of specific buildings and the adoption of coercive regulations implemented by authorised representatives; the process of centralising health measures and their scientific legitimation allowed the responsibility for the organisation of these measures to be transferred, from the $17^{\text {th }}$ century onwards, from local authorities to the states, interconnected with a process that articulated the medicalisation and internationalisation of the health debate on epidemics (Mafart \& Perret, 1998; Logie \& Turan, 2020; Sharma, 2020).

\section{Conclusion}

Representations about contagions and epidemics are shaped, still today, by the view of Thucydides. For Thucydides, the «plague» was not just a sanitary crisis but also a major moral crisis. Nosos, that is, «disease», the infection, did not only destroy the body; nosos, that is, «dementia», also destroyed, even if momentarily, a given society, institutions and traditions. An epidemic was not only the devastation and pain caused by the spread of the infection; it was also the brutal disorganisation that followed, the weakening of the State, the disintegration of authorities, social structures and mentalities. Thucydides spoke of anomie: of mercilessness and lawlessness, of humanity without law or rule (Zylberman, 2012).

There was a reshaping of the aetiology of epidemics and contagions, but the interpretation of evil first ascribed to the sinful Man, to the vindictive God, and then to foreign or deemed dangerous communities, generated a whole set of eschatological beliefs, fears and representations, and in which individual interactions and social relationships at their different scales produce and enhance «Nosos». What relates very different epidemics at the aetiological level is that they have stigmatised affected individuals, groups and communities, as well as the fact that they have been strongly incorporated, both in erudite discourse records and in collective memory and imagery (Zylberman, 2012).

Epidemics and contagions have diverse effects on societies, namely on beliefs, institutions, and social, demographic, economic and political structures. The articulation between impurity, purification and interdiction of contact due to the belief in contagion shapes the symbolic 
management of internal and external dangers, imposing the avoidance of any physical and social approach with patients and other individuals perceived as dangerous in a given community. These behaviours reinforce prejudices and foster stigmatisation processes: against Jews (1347-1350 plague), against the poor in the Renaissance (plague, typhus), against Irish immigrants in the $19^{\text {th }}$ century (cholera), against the poor in the $19^{\text {th }}$ and $20^{\text {th }}$ centuries (tuberculosis), against the four $\mathrm{H}$ (homosexuals, Haitians, haemophiliacs, heroin addicts) in the 1980s (HIV/AIDS), against Africans (Ebola), against Asians and Chinese (bird flu, SARS, Covid-19), against the «stranger», the «foreigner»: the «other»...

The epidemic, as a sanitary crisis, is intertwined with anomie, the expression of a political-moral crisis. The sanitary crisis is an epidemiological, medical crisis, but also a political crisis and a governance crisis. Clinical and epidemiological approaches are interwoven with a political component (power, violence, constraint) and with a governance component (State structure, the behaviour of the governing entities). The State's dominance over sanitary crises depends on its ability to establish, develop and manage complex and specialised organisations (care system and health system, agencies, committees of experts), its ability to ensure the continuity of its functioning and the mobilisation of its resources, and its power of control over the use of coercion in the response to sanitary crises. The crisis is not something that will emerge in the future, or that is going to emerge: it is something that comes, «the pandemic that comes» (Zylberman, 2012).

\section{Acknowledgement}

Funding: University of Azores, Interdisciplinary Centre of Social Sciences CICS.UAc/CICS.NOVA.UAc, UID/SOC/04647/2020, with the financial support of FCT/MEC through national funds and when applicable co-financed by FEDER under the PT202o Partnership Agreement.

\section{References}

Boccaccio, G. (2003). The Decameron. G. H. McWilliam (Introducer). London: Penguin Books

Bonastra Tolós, J. (2006). Ciencia, sociedad y planificación territorial en la institución del Lazareto [Science, society and territorial planning in the establishment of the Lazareto]. Doctoral Thesis. Barcelona: Universitat de Barcelona.

Bonastra, Q. (2010). Recintos sanitarios y espacios de control. Un estudio morfológico de la arquitectura cuarentenaria [Sanitary enclosures and control spaces. A morphological study of quarantine architecture]. Dynamis, 30, 17-40.

Bonita, R., Beaglehole, R., \& Kjellström, T. (2006). Basic epidemiology ( ${ }^{\text {nd }}$ Ed.). World Health Organization. Available at https://apps.who.int/iris/handle/10665/43541

Bourdelais, P. (1989). Contagions d'hier et d'aujourd'hui [Contagions of yesterday and today]. Sciences Sociales et Santé, VII(1), 7-20.

Bourdelais, P. (1998). La construction de la notion de contagion: Entre médecine et société [The construction of the notion of contagion: Between medicine and society]. In J. Cheyronnaud, P. Roussin, \& G. Vigarello (Dirs.), Communications, la contagion, 66, 21-39.

Bourdieu, P. (2014). Sobre o Estado. Curso no Collège de France (1989-1992) [On the State. Course at Collège de France (1989-1992)]. Lisboa: Edições 70.

Bourdieu, P. (2001). Science de la science et réflexivité [Science of science and reflexivity]. Paris: Raisons d'Agir.

Cala, G. (2011). Appel: Contagion/contamination. Appels à contributions/Tracés [Call: Contagion/contamination. Calls for contributions/Tracks] (online). Revue de Sciences Humaines, 21. Available at http://traces.hypotheses.org/61

Carvalho, L. M. (200o). Nós através da escrita: Revistas, especialistas e conhecimento pedagógico (1920-1936) [Us through writing: Magazines, specialists and pedagogical knowledge (1920-1936)]. Cadernos Prestige, 3. Lisbon: Educa.

Cipolla, C. M. (1976). Cristofano e la peste [Cristofano and the plague]. Bologne: Il Mulino.

Cosmacini, G. (1992). Soigner et réformer. Médecine et santé en Italie de la grande peste à la Première Guerre Mondiale [Heal and reform. Medicine and health in Italy from the great plague to the First World War]. 
Paris: Éditions Payot.

Coste, F. Minard, A., \& Robert, A. (2011). Contagions. Histoires de la précarité humaine. Tracés [Contagions. Stories of human precariousness. Tracks]. Revue de Sciences Humaines, 21 [online]. Available at http://traces.revues.org/5126

Cruz, A. (2007/2008). A máscara por detrás do véu do estigma: Cabe o pensamento de Lévi-Strauss numa reflexão sobre a experiência da lepra? [The mask behind the veil of stigma: Does Lévi-Strauss's thought fit into a reflection on the experience of leprosy?]. Antropologia Portuguesa, 24/25. Coimbra, Universidade de Coimbra.

Cule, J. (2002). The stigma of leprosy: Its historical origins and consequences with particular reference to the laws of wales. In C. Roberts, M. Lewis, \& K. Manchester (Eds.), Past and present of leprosy: Archaeological, historical, paleopathological and clinical approaches. Oxford: Archaeopress.

Cunha, A. G. (1982). Dicionário etimológico da língua portuguesa [Portuguese etymological dictionary], Rio de Janeiro: Nova Fronteira.

Czeresnia, D. (1997). Do contágio à transmissão: Ciência e cultura na génese do conhecimento epidemiológico [From contagion to transmission: Science and culture in the genesis of epidemiological knowledge (online)]. Rio de Janeiro: Editora Fiocruz.

Defoe, D. (1966). A journal of the plague year. London: Penguin.

Douglas, M. (1991). Pureza e perigo [Purity and danger]. Lisbon: Edições 70.

Dozon, J. P. (2001). Quatre modèles de prévention [Four prevention models]. In J.-P. Dozon, \& D. Fassin (Dirs.), Critique de la santé publique. Une approche anthropologique [Critique of public health. An anthropological approach] (pp. 23-46). Paris: Éditions Balland.

Dozon, J. P., \& Fassin, D. (2001). L'universalisme bien tempéré de la santé publique (Introduction) [The welltempered universalism of public health (Introduction)]. In J.-P. Dozon, \& D. Fassin (Dirs.), Critique de la santé publique. Une approche anthropologique [Critique of public health. An anthropological approach] (pp. 7-19). Paris: Éditions Balland

Elias, N. (1983). O processo civilizacional [The civilisational process]. II Vol. Lisbon: Edições D. Quixote.

Fabre, G. (1993). La notion de contagion au regard du sida, ou comment interfèrent logiques sociales et catégories médicales [The notion of contagion regarding AIDS, or how social logics and medical categories interfere]. Sciences Sociales et Santé, 11(1), 5-32.

Fabre, G. (1998). Épidémies et contagions. L'imaginaire du mal en Occident [Epidemics and contagions. Evil's imagery in the West]. Paris: PUF.

Fainzang, S. (1994). L'alcoolisme, une maladie contagieuse. Réflexions anthropologiques sur l'idée de contagion [Alcoholism, a contagious disease. Anthropological reflections on the idea of contagion]. Revue Ethnologie Française, XXIV(4), 825-834.

Fassin, D. (1996). L'espace politique de la santé [The political space of health]. Paris: PUF.

Ferreira, C. M. (2020). Fazer o tempo: Sanatório e medicalização [Making the time: Sanatorium and medicalisation]. Porto: Estratégias Criativas.

Fleck, L. (1986). La génesis y el desarrollo de un hecho científico [The genesis and development of a scientific fact]. Madrid: Alianza Editorial.

Flick, U. (2005). Métodos qualitativos na investigação científica [Qualitative methods in scientific research]. Lisboa: Edições Monitor.

Fossier, A. (2011). La contagion des péchés (XIe - XIIIe siècle). Aux origines canoniques du biopouvoir [The contagion of sins $\left(11^{\text {th }}-13^{\text {th }}\right.$ century). The canonical origins of bio-power]. Tracés. Revue de Sciences Humaines, 21 (online). Available at http://traces.revues.org/5126

Foucault, M. (1978). The history of sexuality. Volume I: An Introduction. New York: Pantheon Books.

Hass, V., \& Jodelet, D. (2007). Pensée et mémoire sociales [Social thought and memory]. In J. P. Pétard (Coord.), Psychologie sociale [Social psychology] (pp. 111-16o). Rosny: Éditions Bréal.

Konstantinos, C. (1997). Sous l'aile protectrice de l'État (Abram de Swaan, traduit de l'anglais par L. Bury) [Under the protective wing of the State (Abram de Swaan, translated from English by L. Bury)]. Flux Cahiers Scientifiques Internationaux Réseaux et Territoires, 27-28, 96-101.

Kuriyama, S. (200o). Epidemics, weather, and contagion in traditional Chinese medicine. In L. Conrad Li, \& D. Wujastyk (Eds.), Contagion. Perspectives from pre-modern societies (pp. 3-22). Aldershot: Ashgate.

Lakoff, A. (2007). Preparing for the next emergency. Public Culture, $19(2), 247-271$. https://doi.org/10.1215/o8992363-2006-035

Lakoff, A. (2008). The generic biothreat, or, how we became unprepared. Cultural Anthropology, 23 (3), $399-428$. https://doi.org/10.1111/j.1548- 1360.2008.00013.x

Lalanda-Gonçalves, R. (2014). O documento nas ciências sociais: Construção e contextos sociais [The document in social sciences: Construction and social contexts]. In As transformações do documento no espaço-tempo do 
conhecimento [The transformations of the document in the space-time of knowledge]. III International Conference of the MUSSI Network, Bahia, Brazil, November 10-12.

Logie, C. H., \& Turan, J. M. (2020). How do we balance tensions between COVID-19 public health responses and stigma mitigation? Learning from HIV research. AIDS and Behavior. https://doi.org/10.1007/s10461-02002856-8

Lugt, M. (2010). Les maladies héréditaires dans la pensée scolastique (XIIe-XVIe siècle) [Hereditary diseases in scholastic thought (12th-16 ${ }^{\text {th }}$ century)]. In M. Lugt, \& C. Miramon (Eds.), L'hérédité entre Moyen Âge et époque moderne. Perspectives historiques [The heredity between the Middle Ages and modern times. Historical perspectives] (pp. 273-320) Florence: SISMEL, Edizioni del Galluzzo.

Mafart, B., \& Perret, J.-L. (1998). Histoire du concept de quarantaine [History of the concept of quarantine]. Médecine Tropicale, 58(2), 14-20.

Marques, M. S., \& Ferreira, C. M. (2010). Contágio: Contribuição para a epistemologia e a ética da saúde pública [Contagion: Contribution to epistemology and ethics of public health]. Acta Médica Portuguesa, 23, 533-556.

Martins, C. (2011). Peste e literatura: A construção narrativa de uma catástrofe [Plague and literature: The narrative construction of a catastrophe]. Coimbra: Universidade de Coimbra.

Mozzicafreddo, J. (1998). Estado, modernidade e cidadania [State, modernity and citizenship]. In J. M. L. Viegas, \& A. F. Costa (Orgs.), Portugal, que Modernidade? [Portugal, what modernity?]. Oeiras: Celta Editora.

Neves, L., \& Ferreira, T. (1989). O medo dos “abomináveis princípios franceses”: A censura dos livros nos inícios do século XIX no Brasil [The fear of the "abominable French principles": Censorship of books in the early $19^{\text {th }}$ century in Brazil]. Acervo, Rio de Janeiro, 4(1), 113-119.

Nutton, V. (2000). Did the Greeks have a word for it? Contagion and contagion theory in ancient antiquity. In L. Conrad, \& D. Wujastyk (Eds.), Contagion. Perspectives from pre-modern societies (pp. 137-162). Aldershot: Ashgate.

Nutton, V. (1990). The reception of Fracastoro's theory of contagion. The seed that fell among thorns? Osiris, 2nd series, VI, 196-234.

Paillard, B. (1998). Petit historique de la contagion [Brief history of contagion]. Communications, 66, La Contagion. Paris: Éditions du Seuil.

Pantin, I. (2005). Fracastoro's De contagione and medieval reflection on action at a distance. Old and new trends in Renaissance discourse on contagion. In C. Carlin (Ed.), Imagining contagion in early modern Europe (pp. 3-15). New York: Palgrave Macmillan.

Pelling, M. (1993). Contagion/germ theory/specificity. In W. Bynun, \& R. Porter (Eds.), Companion encyclopaedia of the history of medicine (pp. 309-334). London: Routledge.

Penso, G. (1981). La conquête du monde invisible. Parasites et microbes à travers les siècles [The conquest of the invisible world. Parasites and microbes over the centuries], Paris: Éditions Roger Dacosta.

Pinnel, P. (1998). Médicalisation et procès de civilisation [Medicalisation and civilisation processes]. In P. Aïach, \& D. Delanoë (Dirs.), L'ère de la médicalisation. Ecce homo sanitas [The era of medicalisation. Ecce homo sanitas] (pp. 37-51). Paris: Anthropos.

Ramos, A. G. (1981). The new science of organizations. Toronto: University of Toronto Press.

Robert, A. (2011). Contagion morale et transmission des maladies: Histoire d'un chiasme (XIII ${ }^{\mathrm{e}}$-XIX ${ }^{\mathrm{e}}$ siècle) [Moral contagion and disease transmission: history of a chiasmus $\left(13^{\text {th }}-19^{\text {th }}\right.$ centuries $\left.)\right]$. Tracés. Revue de Sciences Humaines, 21, 41-6o (online). https://doi.org/10.400o/traces.5139

Sharma, S. (2020). Rodents' as public health pests: Identification, surveillance and its management. Journal of Communicable Diseases, 51(4), 47-57.

Swaan, A. (1988). In care of the State. Health care, education and welfare in Europe and the USA in the modern era. Cambridge: Polity Press.

Torny, D. (2012). De la gestion des risques à la production de la sécurité: l'Exemple de la préparation à la pandémie grippale [From risk management to security production: The example of pandemic influenza preparedness]. Réseaux, La Découverte, 3o(171), pp. 45-66.

Zylberman, P. (2012). Crises sanitaires, crises politiques [Health crises, political crises]. Les Tribunes de la Santé, 1(34), 35-50. https://doi.org/10.3917/seve.034.0035 